\title{
Financing Sustainability: The New Transnational Governance of Socially Responsible Investment
}

Benjamin J. Richardson

Osgoode Hall Law School of York University

Source Publication:

Yearbook of International Environmental Law. Volume 17, Issue 1 (2006), p. 73-110.

Follow this and additional works at: https://digitalcommons.osgoode.yorku.ca/scholarly_works (c) (1) $(9)$

This work is licensed under a Creative Commons Attribution-Noncommercial-No Derivative Works 4.0 License.

\section{Recommended Citation}

Richardson, Benjamin J. "Financing Sustainability: The New Transnational Governance of Socially Responsible Investment." Yearbook of International Environmental Law 17.1 (2006): 73-110.

This Article is brought to you for free and open access by the Faculty Scholarship at Osgoode Digital Commons. It has been accepted for inclusion in Articles \& Book Chapters by an authorized administrator of Osgoode Digital Commons. 


\title{
Financing Sustainability: The New Transnational Governance of
}

\section{Socially Responsible Investment}

\author{
Benjamin J.Richardson
}

I.

GOVERNING THE SOCIALLY RESPONSIBLE INVESTMENT (SRI) MAR KET

1. Introduction

The surge in transnational investment in recent decades presents new and unusual challenges to international environmental law. Financial markets are not a collection of disparate national financial systems. Rather, they function increasingly within a single global marketplace. ${ }^{1}$ At the same time, financial regulation remains a product of national laws, mostly designed to facilitate, rather than hinder, global financial flows. ${ }^{2}$ Apart from the European Union (EU), inter-governmental supervision of these Flows is largely at a nascent stage of evolution. ${ }^{3}$ International law typically speaks to the behaviour and responsibilities of states and not to institutional investors and other corporate entities. The result is a transnational financial system 'in which money traverses national capital markets with dramatic speed and callous scrutiny, bringing with it both the ability to enhance local economic opportunities or break an economy at its very core.'

Transnational financial markets are also significant to the environment because they transform money by scale, time, and location into an instrument of development. One possible reaction to social and environmental impacts of capital markets is the emergence of new standards for SRI. In the absence of formal international law outlining environmental rules, a variety of voluntary and other soft law mechanisms have arisen to encourage banks and other financiers to invest 
ethically and sustainably. These mechanisms include the United Nations Principles of Responsible Investment, the Equator Principles, and other like standards. ${ }^{5}$

SRI, which is also known as ethical investment or sustainable finance, depending on its focus, considers social, environmental, and ethical consequences in the provision of capital to companies. By targeting entities that financially sponsor investments, in comparison to frontline companies that extract, consume, and pollute, SRI promises a novel way to achieve sustainability. Sustainability, as a higher-order social goal, concerns the integrity of natural systems (global climate, evolutionary viability of ecosystems, and other vital life-support services) and societal and economic issues (health, human rights, poverty, and so on). ${ }^{6}$

Responsible investment challenges the traditional conceptualization of financial markets as essentially amoral and driven only by economic rationality. Beginning in the 1700s, religious groups led by the Quakers began to eschew investments in sin businesses connected to the slave trade or the production of intoxicants. SRI has since emerged from its ecclesiastical foundations into a broader coalition for socially and environmentally responsible financing. ${ }^{7}$ Among its adherents are pension plans interested in sustainable, long-term investment, specialist ethical mutual funds, and banks that evaluate environmental risks as part of their lending policies. ${ }^{8}$ A broad distinction has evolved in SRI between ethical investment, which is driven by moral imperatives and often a desire for political change, and a less controversial approach that accommodates social and environmental issues when they present 'material' financial risks and opportunities for investors.

Though growing quickly, the SRI sector in its entirety, nonetheless, has captured only a small market. It likely averages just 3-10 per cent of the investment market in major economies. ${ }^{9}$ SRI's clout is thus limited by its market penetration, but, if it could become more mainstream, financial markets could arguably contribute significantly to sustainability. Before this shift can happen, however, reform of financial markets is necessary to remove various market and institutional barriers to SRI, 
such as incentives for short-term financial returns and investors' ignorance of the financial impact of corporate environmental performance.

The time has long passed for environmental regulation to target the financial sector. The domain of environmental law is not intuitively associated with banks, pension funds, and other financiers since law makers typically only connect environmental problems directly to companies that extract, consume, and pollute. Yet, corporate financiers should be seen as the economy's 'unseen polluters,' as they finance activities habitually attributed solely to their borrowers and investees. Financial sponsorship of environmentally harmful development should also place corporate financiers within the cupola of responsibility. The biggest environmental impact of financiers is not their own, direct ecological footprint but, rather, their indirect impacts from the allocation of capital to other businesses. ${ }^{10}$ Corporations are rarely entirely financially self-sufficient and must turn to capital markets for new investment to fuel growth. ${ }^{11}$ Financiers, in turn, can gain influence through their ownership stakes in companies. ${ }^{12}$ Economic growth and its environmental impacts are thus intertwined with financial sector decisions.

A proliferation of institutions and new methods for governance of the sector has contributed to the growth of SRI. These mainly non-state forms of governance are often organized transnationally and furnish both substantive standards for environmentally responsible finance and procedures for more transparent, accountable decisions. ${ }^{13}$ This ensemble of multilayered and fragmented regulation, with little government input, aims to promote the SRI market. ${ }^{14}$ While the use of these mechanisms is mostly voluntary, for some investors the question is no longer whether to use these mechanisms but which ones to apply and how.

This article categorizes these mechanisms of SRI governance into four main types. First, normative frameworks provide governance through the enunciation of substantive principles and guidance on desirable performance. Normative guidelines include the Collevecchio Declaration on Financial Institutions and the 
UN Principles of Responsible Investment. ${ }^{15}$ Second, process standards that enable the assessment, verification, and communication of performance are another form of governance. These standards include the Equator Principles and the Global Reporting Initiative. ${ }^{16}$ Third, management systems, such as the International Organization of Standardization's ISO 14001 regime, provide integrated or issue specific frameworks to guide the ongoing management of environmental and social impacts. Fourth, comparative evaluation mechanisms exist, whereby external entities evaluate and rank corporate performance for the SRI industry. These rating mechanisms include SRI stock market indexes, such as the Dow Jones Sustainability Group Indexes, and SRI think tanks, such as the Social Investment Forum.

These governance mechanisms operate in multi-jurisdictional contexts and financial institutions that function in global markets. ${ }^{17}$ Technological advances and market deregulation have accelerated the geographical mobility of capital in its search for the highest returns. ${ }^{18}$ The globalization of financial services reduces the power of states individually to regulate financial markets. ${ }^{19}$ National regulators may also face capacity and information deficits in supervising enterprises engaged in complex trans-border commerce. Transnational collaboration is also necessary to prevent responsible financiers from suffering competitive disadvantages.

The rest of this article explains what these major SRI governance mechanisms demand of financial institutions, assesses their implementation, and makes some observations about the adequacy of this form of governance for SRI. While multilateral development banks (MDBs), bilateral foreign aid, and export credit agencies still play a key role, private financiers have become more significant and visible. The article does not discuss intergovernmental mechanisms or public financing. These systems raise separate policy issues, which are discussed in other literature. ${ }^{20}$ Nor does it canvass national level reforms for SRI. ${ }^{21}$ The next 


\section{section considers}

the theoretical context within which the voluntary-based regulation for SRI has emerged, before canvassing the actual mechanisms of SRI governance.

Governance is the decision-making process by which society and organizations are controlled and coordinated. ${ }^{22}$ Governance is commonly associated with official regulation, whereby government imposes obligations or constraints on private sector behaviour. ${ }^{23}$ Concomitantly, in an international context, governance traditionally requires intergovernmental cooperation through treaties and other agreements. The weakness of these understandings of governance based on agency or institution is that a government decision can become labelled as being regulatory regardless of whether or not it actually discharges regulatory functions. Conversely, private sector actions can be more influential in controlling corporate behaviour.

Contemporary governance is increasingly dependent on collaboration between the state and non-governmental market and civil societal interests. ${ }^{24}$ In addition, mechanisms of governance are becoming less coercive and are including more informational and incentive mechanisms. ${ }^{25}$ Legal pluralism theory has helped scholars to conceive of regulation as something more than just the activities of the state. ${ }^{26}$ Private codes of conduct and other forms of market-generated accountability programmes are part of these heterogeneous or pluralistic systems of modern governance. ${ }^{27}$ In international law, these initiatives may be known as 'soft law.'28 Market-based ordering governance may match the effectiveness of state regulation, particularly when firms are concerned about their reputations and where it helps forestall 'the less palatable alternative' of official regulation. ${ }^{29}$ These changes in governance resonate with 'reflexive' forms of regulation. As a result of the significant functional differentiation in our social systems, mechanisms promoting corporate social responsibility should arguably operate at the level of specific subsystems (for example, the market). ${ }^{30}$ Rejecting regulatory compulsion, Gunther Teubner reasons that legal systems could best change 
corporate behaviour by targeting companies' internal organizational structures. He explains: '[T]he role of law then is not the external control of the firm's conduct, but the external mobilisation of internal self-control resources.' 31 In contrast to the supposedly heavy hand of command regulation, which seeks to control behaviour directly, a system based on reflexive law 'attempts to create incentives and procedures that induce entities to act in certain ways and to engage in internal reflection about what form that behaviour should take... the state sets goals, but shares more of the responsibility for achieving them with regulated entities.' 32 For instance, requirements to disclose, inform, and consult with stakeholders should help make the practices of companies isomorphic with external public policy demands. More understanding of the connections between environmental risk and financial risk may ensue from the reflexive governance of the financial sector, especially if environmental concerns are enunciated in a way that is comprehensible to financial decision makers. ${ }^{33}$

Reflexive regulation is not just a matter of redesigning government legislation or international treaties. It can also arise through nongovernmental sources of governance, such as voluntary codes of conduct developed by businesses. As the next section explores, voluntary codes may promote reflection and learning and, thereby, encourage a positive cultural change in the management of subject business. ${ }^{34}$ They may also, however, be an excuse to merely tinker marginally with current unsustainable habits and disguise the continuation of business as usual.

3. Voluntary Standards for SRI

Without sufficient international or national regulation to promote SRI, much will hinge upon the willingness of financiers to voluntarily promote environmentally sustainable finance. The voluntary approach, which is often described as corporate social responsibility (CSR) or business self-regulation, is apparently thriving. ${ }^{35}$ The 
expansion of global commerce and finance has fuelled debate over the appropriate and legitimate role of the private sector in responding to environmental and social problems. Industry increasingly participates in discussions concerning social equity and environmental protection, as both a cause and solution to problems. The concomitant reframing of private actors, especially transnational companies (TNCs), from amoral profit-seeking enterprises to 'corporate citizens,' has heightened public expectations of socially responsible behaviour. ${ }^{36}$

In practice, a company's adherence to a voluntary code or other mechanism is seldom if ever purely 'voluntary,' in the sense of doing something autonomously and freely for its own sake. Sometimes, it feels external pressure to act more responsibly. ${ }^{37}$ Voluntary commitments may also be rewarding, providing access to technical assistance, financial aid, professional certification, and public acknowledgement. ${ }^{38}$ Indeed, ecological modernization theorists sanguinely believe that, through a framework of industrial modernity, environmental protection and economic development can be mutually supportive. ${ }^{39}$ Environmental care, in this vein, can facilitate efficiency and improve productivity through a less wasteful use of resources. ${ }^{40}$ Pressure on financial institutions to heed voluntary standards may arise from a threat of mandatory regulation, the prospect of adverse publicity, the need to distinguish themselves in a competitive market, and demands from a local community, customers, or business associations. ${ }^{41}$

Whatever the motivations, voluntary standards are 'voluntary' to the extent that authorities do not formally enforce their adoption. Further, while adoption of voluntary codes is not legally obligatory, it may have legal consequences once they are adopted. ${ }^{42}$ An industry code or standard may generate legal consequences through subsequent contracts among participating firms (for example, a loan covenant between a lender and borrower).

Corporate responses to voluntary standards vary considerably. ${ }^{43}$ Generally, at one extreme, companies that actively address environmental issues view escalating pressures on their 
business reputation as a strategic opportunity to enhance business value by adopting new practices beyond the requirements of environmental law. Alternatively, some firms react negatively, perceiving them as a source of financial risk and liability, which may diminish shareholder value.

As such, the composition of actors and interests that make up the institutional milieu of a particular firm and the nature of its stakeholder relationships determine how a firm conceptualizes challenges to its corporate reputation. For example, a project-lending bank closely monitored by nongovernmental organizations (NGOs) may face relatively high reputational risks from irresponsible financing decisions. Conversely, a pension fund that is not directly involved in development financing decisions and is insulated from normal market pressures, may face less societal scrutiny. Therefore, investing in companies with unsound environmental practices is less risky.

Some scholars and policy makers remain sceptical that voluntary mechanisms provide a viable means of public policy and doubt their legitimacy as instruments of environmental or social regulation. ${ }^{44}$ This criticism has some merit. Various empirical research casts doubt on the effectiveness of voluntary measures to significantly mitigate corporate environmental harm. ${ }^{45}$ For instance, the European Commission recently made emissions requirements on car manufacturers mandatory because the automobile industry had failed to meet its own voluntary code of $1998 .{ }^{46}$ Ideally, voluntary mechanisms create an institutional context whereby civil society can directly engage with companies and obtain information about their practices. More commonly, however, voluntary measures lack transparency and accountability. ${ }^{47}$ In fact, they may pre-empt regulation and thereby forestall meaningful change. ${ }^{48}$ In addition, negotiation and development of voluntary measures carry transaction costs. Further, there is the perennial danger of free riding, whereby non-participants exploit the benefits of a voluntary regime without contributing to its costs. ${ }^{49}$ For example, although many financial institutions have declined to support China's Three Gorges Dam project or Peru's Camisea natural gas project, some banks did not share these negative views and stepped in to provide the necessary loans. ${ }^{50}$ Overall, without careful design and enforcement, 
voluntary measures may do little to promote sustainability and become a reprehensible means to perpetuate business as usual.

I. NORMATIVE FR AMEWOR KS

1. Introduction

A common governance mechanism for SRI involves codes that are developed by third parties, which organizations are invited to implement. Third parties may include environmental NGOs, industry associations, international technical standardization bodies, or an inter-governmental entity such as the United Nations. ${ }^{51}$ The international codes most relevant to SRI are enumerated in Table 1.52

Table 1: Voluntary Codes of Conduct Relevant to Socially Responsible Investment

\begin{tabular}{|c|c|}
\hline Code of Conduct & Principal Sponsor \\
\hline CERES Principles & $\begin{array}{l}\text { Coalition for Environmentally Responsible } \\
\text { Economies }\end{array}$ \\
\hline Collevecchio Declaration & $\begin{array}{l}\text { Coalition of non-governmental } \\
\text { organizations }\end{array}$ \\
\hline Global Sullivan Principles & Reverend Leon Sullivan \\
\hline London Principles of Sustainable Finance & $\begin{array}{l}\text { UK Department of Environment and } \\
\text { Corporation of London }\end{array}$ \\
\hline UN Global Compact & United Nations \\
\hline UN Principles of Responsible Investment & UN Environment Program Finance Initiative \\
\hline $\begin{array}{l}\text { UN Statement by Financial Institutions } \\
\text { on the Environment and Sustainable } \\
\text { Development }\end{array}$ & UN Environment Program Finance Initiative \\
\hline $\begin{array}{l}\text { UN Norms on the Responsibilities of } \\
\text { Transnational Corporations }\end{array}$ & $\begin{array}{l}\text { UN Sub-Commission on Promotion and } \\
\text { Protection of Human Rights }\end{array}$ \\
\hline
\end{tabular}

Apart from the UN norms, none of these codes are formal inter-governmental initiatives. ${ }^{53}$ For the two UN Environment Programme (UNEP)-sponsored codes, UNEP simply coordinates and facilitates the process for businesses and other non-governmental participants. The following discussion covers only a representative sampling of these codes, namely those governance approaches that address SRI directly rather than corporate behaviour generally or that have garnered the most debate in the SRI community. Consequently, this article does not consider the UN Global Compact, ${ }^{54}$ CERES Principles, ${ }^{55}$ London Principles, ${ }^{56}$ or the Sullivan Principles. ${ }^{57}$ 


\section{UNEP's Finance Initiative (UNEPFI)}

The first transnational code specifically for SRI was developed by UNEPFI. ${ }^{58}$ The finance initiative has become a catalyst for bringing environmental issues to the attention of global financial markets. Established in 1991 and headquartered in Geneva, UNEPFI is a public-private partnership. ${ }^{59}$ It promotes education and research on SRI and the design of SRI management tools. ${ }^{60}$ In 1992 it released its first code, the Statement by Banks on Environment and Sustainable Development, for banks to manage environmental risks. ${ }^{61}$ In 1995 UNEPFI sponsored a similar statement for the insurance industry. ${ }^{62}$ In May 1997 UNEPFI issued a more general, umbrella code for all financiers-the Statement by Financial Institutions on the Environment and Sustainable Development. ${ }^{63}$ Although the statement is short on measurable, concrete specifics, it has relatively ambitious standards for environmental risk assessment and public reporting on environmental policy and practice. ${ }^{64}$ Commendably, the statement primarily targets the influence that financiers have over the environmental performance of their borrowers and clients. Over 200 institutions have signed UNEPFI's 1997 statement, including commercial banks, venture capitalists, and asset managers. ${ }^{65}$

Despite its global reach, the impact of UNEPFI has probably been modest. The lack of transparency that characterizes the operation of most financiers hinders an assessment of the extent to which signatories actually meet their commitments. A European survey in 1998 to monitor implementation of the UNEPFI statements found that the majority of the sixty-three respondents had a dedicated environmental unit and specific environmental policies and procedures for corporate credit and project finance. Environmental policies and procedures were relatively uncommon in the investment banking and insurance sectors. ${ }^{66}$

Prior to 2000, UNEPFI was a tiny operation employing just two core staff. Apart from its sustainable finance statements, UNEPFI served mainly to network environmental risk experts in the financial sector. ${ }^{67}$ By 2006 UNEPFI had expanded to at least fifteen staff 
and taken on more activities. UNEPFI signatories may participate in training and workshops, taskforce meetings, global roundtables, and themed conferences sponsored by the initiatives. ${ }^{68}$ UNEPFI facilitates various working groups to target specific issues ${ }^{69}$ and regional taskforces for banks and insurance companies in North America, Asia-Pacific, and other regions. ${ }^{70}$ All of these efforts essentially focus on creative ways to improve appreciation of the links between finance and sustainability.

3. UN Principles of Responsible Investment (UNPRI)

The UNPRI, which was developed under the auspices of UNEP, principally address institutional investors. They were adopted because the UNEPFI statements, which focus on banks and insurers, were not considered by the SRI community to provide an adequate framework for responsible financing in the institutional sector. ${ }^{71}$ The UNPRI were drafted by a group of invited investment professionals mainly from the pension fund sector and were supported by a seventy-person multi-stakeholder collection of experts from the investment industry, inter-governmental, and governmental organizations, civil society, and academia. Friends of the Earth (FOE) and the Worldwide Fund for Nature (WWF) were among the NGOs involved. UNEP was not formally involved in the drafting of the UNPRI because its involvement would have required the principles to be developed through a formal intergovernmental process, which would have been too slow and politically complicated. ${ }^{72}$ Therefore, the UNPRI became an industry-led initiative, in which UNEP simply coordinated and facilitated the negotiations.

The UNPRI is a brief document of six core principles, each of which is illustrated by thirty-five 'possible actions' to achieve them. The principles are:

- We will incorporate environmental, social, and corporate governance (ESG) issues into investment analysis and decision-making processes.

- We will be active owners and incorporate ESG issues into our ownership policies and practices. 
○ We will seek appropriate disclosure on ESG issues by the entities in which we invest.

- We will promote acceptance and implementation of the principles within the investment industry.

○ We will work together to enhance our effectiveness in implementing the principles.

- We will each report on our activities and progress towards implementing the principles. $^{73}$

The accompanying 'possible actions' amount to a 'best practice' guide. Concerning the second principle, for instance, the possible actions specified to achieve active ownership include 'exercising voting rights,' 'developing an engagement capability,' and 'filing shareholder resolutions consistent with long-term ESG considerations.' The principles are intended for signature by three types of institutions: asset owners (for example, pension funds), investment managers (intermediaries who manage funds on behalf of others), and professional service partners (for example, stock exchanges). As of late 2007, approximately 2000 institutions had signed the principles, holding about US $\$ 10$ trillion in assets under management. ${ }^{74}$

\section{Will the UNPRI lead to a fundamental transformation in investor behaviour towards} sustainability? According to the principles' sponsor, [i]mplementing the Principles will lead to a more complete understanding of a range of material issues, and this should ultimately result in increased returns and lower risk. Signatories will be part of a network, which creates opportunities to pool resources, lowering the costs of research and active ownership practices. The Principles also allow investors to work together to address a range of systemic problems that, if remedied, may then lead to more stable, accountable and pro5table market conditions overall. ${ }^{75}$ As a normative framework for SRI, the principles have some notable shortcomings. For the first principle, among the list of possible actions, investors are not expected to actually incorporate ESG factors into their portfolio choices, such as to apply ethical asset selection screens. The second principle on active ownership focuses on participation in investee 
companies while incongruously ignoring the imperative of democratizing decision making within financial institutions themselves.

Unlike some other voluntary codes and standards, the UNPRI do not provide for any independent audit or verification mechanism to assess the quality of signatories' implementation. Nor is there any upfront requirement for a prospective signatory to demonstrate any particular SRI performance standards, thereby limiting their effectiveness. To sign up, an investor need only e-mail an expression of interest, followed by a statement of commitment ratified by their governing investor board. The UNPRI website explains:

There are no legal or regulatory sanctions associated with the Principles. They are designed to be voluntary and aspirational. There may be reputational risks associated with signing up and then failing to take any action, but the commitments are, for most signatories, a work in progress and a direction to head in rather than a prescriptive checklist with which to comply... As the project develops overtime, the Board will consider how signatories can monitor and report on progress. ${ }^{76}$

However, rigorous oversight from the UNPRI governing board cannot be expected. The governing board, a majority of whom are asset owners, are elected from within the asset owner category of signatories. Yet, despite these shortcomings, the UNPRI have been generally well received by the finance sector and civil societal institutions. ${ }^{77}$ In recent years, many asset owners have signed up. Whether this enthusiasm will drive positive changes in their behaviour is yet to be determined.

UN Norms on the Responsibilities of Transnational Corporations Another international standard connected with the United Nations is the UN Norms on the Responsibilities of Transnational Corporations and Other Business Enterprises with Regard to Human Rights (UN Norms). ${ }^{78}$ They apply to a range of TNCs, including investment companies and other investment intermediaries. In contrast to other instruments discussed in this article, the UN Norms are intended to be legally binding if and when they are adopted by states. The UN Norms, which formalize the types of demands originally made by developing countries at 
the UN Commission on Transnational Corporations in the 1970s, mainly address labour standards and consumer protection. ${ }^{79}$ They also contain several environmental provisions. They call upon TNCs to observe the precautionary principle and to act 'in a manner contributing to the wider goal of sustainable development.' 80 They go so far as to demand TNCs to respect a societal 'right to a clean and healthy environment.' 81

The UN Norms contain several procedural requirements for their implementation. ${ }^{82}$ While they accommodate a role for the state, ${ }^{83}$ the UN Norms expect TNCs to 'adopt, disseminate and implement internal rules of operation' and 'to periodically report' 84 on their progress 'to all relevant stakeholders. ${ }^{95}$ Importantly, TNCs are further compelled to 'apply and incorporate [the] Norms in their contracts or other arrangements and dealings' with almost any and every party with whom they do business. ${ }^{86}$ Where their contracting partners violate these terms, TNCs are required to 'cease doing business with them.' 87 Sanctions for non-compliance may include compensation that is determined by national and/or international courts to affected persons and other entities. ${ }^{88}$ With these requirements, the UN Norms seek in an unprecedented way to circumvent state authority and impose international legal obligations directly on TNCs.

The UN Norms thus herald a radical departure from previous intergovernmental attempts to govern TNCs. Their most polarizing trait is their imposition of obligations directly on corporations, in addition to concomitant duties on states. ${ }^{89}$ This attribution attempts to overcome one of the main governance gaps concerning TNCs, namely the fact that due to their transnational nature, they often operate in a legal vacuum, particularly in states that are themselves deeply mired in environmental and human rights abuses. Yet it is an unorthodox approach in international law. Many companies and their associations, such as the International Chamber of Commerce, have criticized the UN Norms for shifting the obligation to protect human rights and the environment 
from governments to private companies.

These considerations have weighed on the UN Commission on Human Rights, which declined to endorse the UN Norms. ${ }^{90}$ A report by John Ruggie, UN special representative on human rights and business, was critical of the form and reach of the UN Norms and viewed the initiative as creating 'confusion and doubt' through 'exaggerated legal claims and conceptual ambiguities.'91 Even though the United Nations may never formally adopt the UN Norms, some SRI institutions are beginning to refer to them in their shareholder resolutions and proxy-voting guidelines. ${ }^{92}$ The Interfaith Center for Corporate Responsibility, for example, which coordinates SRI among religious investors, has endorsed the UN Norms. ${ }^{93}$ They would likely help bolster SRI by focusing on the environmental behaviour of companies and those that finance them.

4. Collevecchio Declaration

Civil societal groups that are critical of facile, business-friendly codes of conduct have offered financial institutions an alternative standard. In 2003 a coalition of NGOs drafted the Collevecchio Declaration on Financial Institutions (Collevecchio Declaration), ${ }^{94}$ comprising six principles that stress accountability, transparency, and stakeholder rights. Since groups outside of the financial sector have prepared it, the Collevecchio Declaration presents itself as a more credible code. On the other hand, this design is also a disadvantage since the declaration has little buy-in from the financial sector. As of late 2007, approximately 100 organizations, mostly NGOs, have endorsed the declaration. ${ }^{95}$ Very few endorsements have come from financial institutions.

The Collevecchio Declaration requires financiers' commitment to sustainability, 'no harm' responsibility, accountability, transparency, and sustainable markets and governance. The declaration differs from other normative standards through its more rigorous and detailed requirements.

The 'commitment to sustainability' principle obliges investors to expand their missions from 
ones that prioritize pro5t maximization to a vision of social and environmental sustainability. A commitment to sustainability would require financial institutions to fully integrate the consideration of ecological limits, social equity and economic justice into corporate strategies and core business areas (including credit, investing, underwriting, advising), to put sustainability objectives on an equal footing to shareholder maximization and client satisfaction, and to actively strive to 5nance transactions that promote sustainability.

Concomitantly, the declaration emphasizes precaution and the avoidance of harm rather than merely the mitigation of impacts, as in some other codes. It also seeks to strengthen financiers' accountability and transparency beyond the requirements of rival codes. On transparency, for instance, it advises financial institutions to be 'responsive to stakeholder needs for specialized information' and that 'commercial confidentiality should not be used as an excuse to deny stakeholders information.'

The declaration's accompanying implementation document usefully elaborates these principles and gives financiers specific guidance for promoting environmentally sound financing. For example, concerning the commitment to transparency, it provides:

(a) Corporate Sustainability Reporting

Financial institutions should publish annual sustainability reports according to an internationally recognized reporting format supported by civil society. Financial institutions should further include disclosure on the sustainability profile of the financial institution's portfolio, a breakdown of core business activity by sector and region, and the implementation of the financial institution's sustainability policies and objectives.

For now, these and other Collevecchio standards are possibly too demanding for many banks and other financiers to accept. As the following section discusses, banks have favoured the Equator Principles to manage their social and environmental activities because this code was developed largely by the banking community itself and gives lenders greater leeway and discretion.

\section{Equator Principles}

\section{PROCESS STANDARDS}

A. Overview of the Standards 
In the project finance market, the Equator Principles (EPs) provide lenders with a framework to consider social and environmental issues. ${ }^{96}$ Project finance means loans for specific projects such as highways, dams, factories, and other major economic investments that often have a substantial ecological footprint. Formulated primarily by the banking industry under the auspices of the World Bank's International Finance Corporation (IFC), the EPs target private, commercial lending in developing countries and emerging economies where environmental regulation may be tenuous. While the EPs are categorized in this article as being primarily process standards, they also include a normative framework through their incorporation of the IFC's performance standards.

The EPs arose from pressure from financial institutions such as the Calvert Group and Insight Investment, as well as from demands from NGOs including the WWF and the FOE. ${ }^{97}$ The financing of the Chad-Cameroon oil pipeline was the specific catalyst for such pressure. ${ }^{98}$ Fearing a volley of criticism if they supported this controversial project or the risk that they would lose business to unscrupulous lenders if they insisted on strict environmental safeguards, a cohort of banks sought a new level playing field for responsible project financing. To boost the credibility of the proposed standards, the banks involved the IFC in the process. The IFC is the World Bank's private-sector lending arm, with extensive hands-on experience with project finance, including the application of sustainability standards.

The EPs were finalized in June 2003 and revised in April 2006. ${ }^{99}$ The EPs are not self-contained but incorporate reference to other standards, primarily the IFC's environmental and social performance, which address, inter alia, social and environmental impact assessment (SEIA), natural resource conservation, indigenous peoples, involuntary resettlement, labour, and so on. The EPs apply to projects with a total capital cost of at least US $\$ 10$ million (which was previously US \$fi0 million). The revised principles extend to upgrades or expansions of existing projects where additional environmental or social impacts are significant. All signatories to the EPs pledge to provide loans only to borrowers who conform to the principles. 
The EPs initially require lenders to rate projects that they plan to finance based on the magnitude of potential impacts and risks in accordance with the screening criteria of the IFC. 100 These criteria categorize projects as $\mathrm{A}, \mathrm{B}$, or C (high, medium, and low), depending on the potential environmental and social impact of the project. For A and B projects, the borrower must undertake a SEIA based on IFC standards to address issues identified in the screening process. Project-financing banks must also prepare an action plan based on the conclusions of the SEIA. ${ }^{101}$ For category C projects, which are of lesser impact, no further assessment is required beyond the initial screening.

For all category A and B projects, lenders must ensure that the borrower has consulted 'in a structured and culturally appropriate manner.' ${ }^{102}$ The SEIA report and action plan must be publicly available in a local language for a reasonable period to allow for public comment. These documents are also subject to independent expert review. ${ }^{103}$ The borrower must also establish a 'grievance mechanism' to allow it to 'receive and facilitate resolution of concerns and grievances about the project's social and environmental performance raised by individuals or groups from among project-affected communities. ${ }^{\prime 104}$ Prior to drawing on the loan, the borrower must covenant with the lender to (1) comply with the environmental management plan in the construction and operation of the project; (2) provide regular reports on compliance with the plan; and (3) where applicable, decommission facilities in accordance with an agreed plan. ${ }^{105}$

\section{B. Response of the Banking Community}

Given the banking community's heavy involvement in the actual design of the EPs, it is not surprising that banks have generally welcomed the principles. As of June 2007, approximately fifty banks and related financial institutions had pledged themselves to the principles, accounting for over 80 per cent of the global project financing market. ${ }^{106}$ Most of the signatories are North American or western European banks. A study by the British law firm Freshfields Bruckhaus Deringer concluded 
that the EPs 'impact on the financial market generally and their success in redefining banking considerations has been far greater than anyone could have predicted.' 107

The EPs have appealed to banks for several reasons, including the fact that they counter stakeholder and NGO activism, protect market share, maintain a level business playing field, incorporate voluntary standards, and minimize financial risks. ${ }^{108}$ For some lenders, subscription to the EPs offers public relations benefits to counter increasing NGO scrutiny of their environmental and social behaviour. ${ }^{109}$ For instance, following a 2005 shareholder proposal filed to the Bank of Montreal by the Ethical Funds Company, the resolution was withdrawn after the bank agreed to adhere to the EPs. ${ }^{110}$ Similarly, the Rainforest Action Network was particularly successful in its global finance campaign to get Citigroup, the world's largest bank, to change its policies to avoid destructive investment in endangered ecosystems. ${ }^{111}$

\section{Implementation of the EPs}

The 2006 revisions to the EPs have improved their accountability, transparency, and enforceability, although not to the satisfaction of all critics. ${ }^{112}$ Significantly, a lender's categorization of a project or the scope of an environmental impact assessment (EIA) or management plan cannot readily be challenged. The categorization of a project is crucial for it influences the types of environmental standards and procedures that would subsequently apply. Normally, environmental legislation would allow interested persons to review and challenge such a threshold decision. While affected groups may comment publicly on a SEIA or a proposed management plan, they do not have the legal rights to challenge such plans, since EPs are voluntary and therefore do not make this provision. Moreover, the language of the principles is vague. For example, the assessment of projects need only 'refer to' the IFC standards.

The EPs, however, require the lender to appoint an independent environmental expert to monitor all category A projects and, 'as appropriate,' all category B 
projects. ${ }^{113}$ Further, 'at least annually,' the lender must disclose to the public its 'implementation processes and experience, taking into account appropriate confidentiality considerations.' ${ }^{114}$ While these measures should help to illuminate lenders' implementation efforts, the EPs lack a supporting secretariat to coordinate oversight. BankTrack, an umbrella organization of NGOs, has relentlessly criticized the Equator banks. Its 2005 review of the principles (before revisions) concluded that the majority of lenders provided only limited reporting of their implementation of the EPs. ${ }^{115}$ BankTrack also found some hesitancy among Equator banks to disclose the details (for example, names, locations, facilities) of projects that they had financed or declined. ${ }^{116}$ Most recently, in May 2007, BankTrack raised concerns about the growing role of Chinese banks in project lending and their failure to commit to responsible financing. ${ }^{117}$ On the other hand, a report by Freshfields Bruckhaus Deringer more optimistically suggested that the principles have led some Equator banks 'into more structured dialogue with stakeholders and NGOs about social and environmental aspects of their lending.' 118

On enforceability, the EPs disclaim that they confer 'any rights in, or liability to, any person.' Thus, the Equator banks do not see the Principle 6 grievance mechanism as a formal dispute resolution system that can confer obligations or liabilities against them. Further, while borrowers must adhere to environmental covenants included in the loan agreement, lenders themselves are not contractually bound to comply with the EPs or to enforce them against their borrowers. Theoretically, shareholders of a publicly listed Equator bank might contend that they have relied on their bank's public statements that it abides by the EPs. In some jurisdictions, this false communication would enable shareholder suits where the bank's reputation (and, therefore, the business and shareholder value) has suffered because of a failure to implement the EPs. ${ }^{119}$

Evidence so far suggests that implementation of the principles has been patchy. 
Some projects appear to have been rejected for incompatibility with EP standards, while other sources point to Equator banks still funding unsustainable projects. ${ }^{120}$ The banks' own corporate sustainability reports shed some insight. Barclays Bank, for example, discloses in its glossy Corporate Responsibility Report 2005 that it considered fifty highand medium-risk projects and declined twenty-two. ${ }^{121}$ Other factors besides environmental concerns have no doubt played a part here. HSBC boasts that in 2005 it rejected seven projects of sixty-seven that it reviewed for compliance with the EPs. ${ }^{122}$

Several major, international infrastructure projects have tested the credibility of the EPs. One is the Baku-Tbilisi-Ceyhan (BTC) pipeline running through Azerbaijan, Georgia, and Turkey to bring Caspian Sea oil to the West. ${ }^{123}$ According to BankTrack, this project, which was funded by a consortium of financiers including some Equator banks, violates the EPs in regard to protection of indigenous peoples and ecologically sensitive terrain. However, the pipeline development consortium has in many respects applied the EPs openly. They created a publicly accessible website, ${ }^{124}$ where anyone can consult environmental assessments and related documents, many of which are published in local languages. The BTC case shows that an Equator bank may be fully in conformity with decision-making procedures laid down by the principles yet, ultimately, still fund a development that many see as being unsustainable.

Another controversial project testing the credibility of the EPs is the Uruguayan pulp mills proposed near the Rio Uruguay, bordering Uruguay and Argentina. The mills, which pose many environmental hazards, have engendered much dispute between the countries including litigation in the International Court of Justice. ${ }^{125}$ In November 2006 the IFC approved a $\$ 170$ million investment in the Orion pulp mill, one of the two mills, the majority of which is owned by Finnish company Oy Metsä-Botnia Ab. ${ }^{126}$ IFC endorsement has made it easier to garner private lenders for the Uruguay pulp mills, although some Equator banks have declined. ${ }^{127}$ The NGO community and Argentina itself remain deeply 
concerned. A report on Financing Pulp Mills by the Center for International Forestry Research, contends that the SEIA submitted by Oy Metsä-Botnia Ab 'falls far short of what a proper assessment of the mill should consider.' ${ }^{28}$ It also faulted an assessment process that began after the projects were well advanced.

Given the structure of project financing, it is perhaps unrealistic to expect the EPs to revolutionize lending practices. In developed country markets, major projects usually require an EIA to be prepared in order to obtain relevant approvals for undertaking the project. Consequently, the application of the EPs would not significantly increase compliance costs or burdens faced by project sponsors or borrowers except perhaps in subtle ways, such as the extent of public consultation. In emerging markets, which is the intended domain for the EPs, environmental assessments are often not routine, and, consequently, the principles may create additional compliance costs for lenders. Project financers, however, have other reasons to take notice of environmental issues, including reputational risks or financial hardship for borrowers repaying a pollution fine. ${ }^{129}$ Even when a bank has sufficient motivation, its potential leverage over a borrower can be limited because banks often do not get involved in a financing deal until after the basic project choices and design decisions have already been made. ${ }^{130}$ Further, determined would-be borrowers have ways to circumvent an Equator bank's demands, such as by self-financing a project using shareholder funds or the bond market. ${ }^{131}$ This fact points to the need for more comprehensive solutions to promote SRI throughout financial markets rather than merely within the project finance context.

\section{Global Reporting Initiative (GRI)}

The GRI, which was launched by CERES and UNEP in 1997, is a multi-stakeholder process creating an internationally applicable framework for reporting on sustainability issues. $^{132}$ The GRI furnishes reporting principles and specific indicators to guide sustainability reporting for companies and other organizations. GRI Sustainability Reporting Guidelines (known as G-3, being the third generation of guidelines) were issued in 2006. ${ }^{133}$ They consist of reporting principles, reporting guidance, and standard 
disclosures. The reporting principles are materiality, stakeholder inclusiveness, sustainability context, and completeness.

Appreciating the limits of a homogeneous reporting framework, the GRI has created sector-specific supplements. The financial sector supplement focuses on unique environmental impacts associated with financial services and products. ${ }^{134}$ Reporting standards use thirteen environmental performance indicators, such as 'description of process[es] for assessing and screening environmental risks in core business lines' and 'description of voting policy on environmental issues for shares over which the reporting organisation holds the right to vote shares or advise on voting.' ${ }^{135}$ The governance structure of the GRI has enabled a broad range of stakeholders to influence the reporting guidelines and is thus reflective of their concerns and objectives. The consensus-making approach increases the GRI's legitimacy and applicability. On the other hand, the GRI is not a management tool. It guides non-financial reporting and must be complemented by a separate corporate environmental management system (EMS).

The GRI has become the dominant standard for non-financial reporting. A 2005 KMPG analysis of corporate reporting trends found changes in both the style and scale of environmental reports. ${ }^{136}$ First, the focus of reporting has evolved from mainly purely environmental reporting until the late 1990s to sustainability (social, environmental, and economic) reporting, reflective of changes to the GRI guidelines themselves. Second, on the scale of changes, KMPG found that sustainability reporting has become more mainstream among the majority of large companies surveyed. ${ }^{137}$ Of the respondents interviewed, 40 per cent noted that the GRI was determinative of the content of their company's sustainability report. ${ }^{138}$ Other studies have verified the increasing status of the GRI guidelines. ${ }^{139}$ The SRI 
community has sought to promote use of the GRI among financial institutions. ${ }^{140}$ However, the quality of GRI reporting by some financial institutions has been disappointing. Many simply report on their direct, in-house activities rather than the broader environmental risks and impacts of their clients and borrowers. ${ }^{141}$

\section{ISO 14000 Series}

\section{MANAGEMENT SYSTEMS}

Like reporting mechanisms, EMSs help financial institutions to assess their own or their clients' environmental performance. ${ }^{142}$ An EMS is a group of standards and processes that organizations may adopt to improve their internal use of materials and energy and a structure for organizations to identify, appraise, and minimize their environmental risks. An EMS can help a business make production cost savings and gain a better market reputation. ${ }^{143}$ Several internationally applicable EMSs can aid SRI. ${ }^{144}$ The most important are the International Organisation for Standardization (ISO) 14000 series $^{145}$ and the EU's Eco-Management and Audit Scheme (EMAS). ${ }^{146}$

The ISO, which is an umbrella organization for a network of national standards institutes from over 1 fi0 countries, has produced numerous technical standards to facilitate technology exchange and trade. ${ }^{147}$ Its first EMS was the ISO 14000 series, encompassing management system principles, environmental auditing, and life cycle assessment. There is no official ISO standard for the financial services sector as such. All of the ISO 14000 series take the form of 'guidance,' with the exception of the ISO 14001, which is a certificated standard. ${ }^{148}$ It requires participating organizations to develop an environmental policy statement; a corporate plan to achieve environmental goals and comply with legislation; and a monitoring system. The aim is a process by which businesses may reflexively learn to identify and eliminate environmentally damaging activities. ${ }^{149}$ Yet, while ISO compliance indicates the existence of management controls, it does not signify an absolute level of performance.

The ISO has decided to develop a new voluntary standard on corporate social 
responsibility that may prove particularly beneficial for SRI. The guidance standard will be published in 2008 as ISO 26000. ${ }^{150}$ It will not, however, include specific requirements and will thus not be a certification standard like the ISO 14001. The financial sector is taking a growing interest in ISO 14001 both for itself and its clients. ${ }^{151}$ Banks have been most interested, and, in 1999, the UBS (a Swiss bank) was the first lender to be certified. ${ }^{152}$ The Credit Suisse Group, which also has ISO 14001 certification, has spoken of its advantages: '[B]eing certified improves the marketing of the green and ethical funds we offer to our institutional and retail customers.' ${ }^{153}$ In asset selection, Credit Suisse explains 'it is much easier to select stocks of ISO 14001-certified companies for a green and/or ethical fund.' ${ }^{154}$ And it believes that 'having a certified EMS speeds up risk assessment because all relevant environmental data is already available or quickly obtained.' ${ }^{155}$

2. Eco-Management Audit Scheme (EMAS)

The EMAS differs from ISO 14000 by seeking continuous performance improvements and public disclosure of environmental auditing findings. ${ }^{156}$ Participating organizations voluntarily agree to install an EMS (usually for discrete physical sites) and prepare performance reports for verification by a certified environmental auditor at least once every three years. Those that achieve the performance standards can market an approved emblem in their advertisements and promotions. ${ }^{157}$ The organizations must also formulate an environmental policy statement for verification by an independent auditor, which is also made available to the public. The EMAS is considered a good example of a reflexive environmental law since it encourages awareness raising and the disclosure of environmental impacts within industry. ${ }^{158}$

The EMAS was amended in 2001 to broaden its scope to, inter alia, financial services. ${ }^{159}$ Previously, the EMAS was structured around discrete physical sites rather than organizations per se, such as the whole operations of a company. Before 2001, countries could only extend the EMAS provisions to the service sector on an 
experimental basis, ${ }^{160}$ as Austria and Germany did so for banking and insurance industries. ${ }^{161}$ The new focus is on the organization itself not on its physical location. This change was crucial for the EMAS to encompass the financial sector. Further, under Annex VI of the EMAS, an organization can only be certified if it considers all environmental aspects of its activities, including 'indirect environmental aspects' arising from 'capital investments, granting loans and insurance services.' 162 This change is seminal because a financial organization's direct ecological footprint (for example, its energy use and waste) is markedly lower than the impact of its borrowers and customers, which are much more pervasive. However, promotional material for the financial sector suggests that the EMAS remains targeted primarily at the direct ecological footprint of financiers' activities, including consumers of resources such as paper and energy and extending to their supply chains. ${ }^{163}$ Financial institutions that are EMAS certified include UniCredito Italiano and Oesterreichische Nationalbank.

\section{Potential of the EMS}

By summarizing environmental performance data, EMSs can help financiers efficiently assess the risks posed by clients. Insurance markets were the first sector to acknowledge firms' accreditation to EMSs. ${ }^{164}$ Significant discounts on environmental liability insurance premiums were offered to chemical manufacturers that subscribed to the Responsible Care EMS. ${ }^{165}$ Some banks offer finance on preferential terms to EMS-certified borrowers. ${ }^{166}$ Davies suggests: '[B]y looking for [EMS] registration in loan applications, banks can determine several facts relevant to the health of their loan portfolios.' 167 Yet because EMSs tend to look at existing rather than future environmental performance, they must usually be supplemented with regular verification to retain their validity.

While the propagation of corporate EMSs provides a welcome framework for reflexive 
management and environmental self-organization, the approach has some limitations. ${ }^{168}$ From a regulatory perspective, EMSs may be unsatisfactory to the extent that they favour private over public interests. ${ }^{169}$ Nor can free-riding third parties be forced to comply given the voluntary nature of the process, unless governments legislate minimum environmental standards and offer inducements to companies. Furthermore, EMSs are essentially procedural, requiring that companies have a system for managing environmental issues. The substantive goals that a company selects as the basis of its EMS may be facile so that it can achieve the desired standards at little inconvenience. ${ }^{170}$ Greater involvement of environmental NGOs in the design of EMS standards may help make them more publicly acceptable and take firms beyond business as usual. ${ }^{171}$

\section{COMPARATIVE EVALUATION MECHANISMS}

1. Sustainability Indexes

\section{A. Function and Structure of Sustainability Indexes}

Sustainability indexes are a relatively new SRI governance tool to assess and compare the social and environmental performance of public companies. A sustainability index is a special type of market index. A market index tracks price movements of listed financial securities within it. By comparing market values of selected companies over time, a graph can be constructed to show changes in their value. A sustainability index is distinctive as it only includes firms that meet specified environmental and social criteria, in addition to demonstrating financial robustness. Each index has its own criteria for inclusion and methods for collecting data on companies' performance. Official stock exchanges and private SRI research institutions have both established sustainability indexes, as detailed in Table 2.

The criteria and rules that govern inclusion in each index help to improve the integrity of the SRI market in three crucial ways. First, the methodologies to select and rank companies constitute a normative benchmark for the whole SRI market including companies not formally included in any index. Second, they 
provide sustainability benchmarks against which to compare performance. Responsible investors may rely on such indexes, as both a benchmark to compare the progress of their SRI portfolio to the sustainability index and as a means of picking assets that comply with the investor's preferred environmental and social criteria. Third, the ultimate membership selections of the SRI indexes constitute an instrument of market ordering. Companies that seek competitive advantages from association with a prestigious sustainability index are disciplined to adhere to the index criteria of membership. Each index helps communicate the standards of social investors to corporations in an understandable format. Together, these characteristics make sustainability market indexes a unique enforcement mechanism for corporate governance standards since removal of a company from an index focuses the attention of owners as well as management in a way that bad publicity or condemnation by an institutional investor is unlikely to accomplish alone. 
Table 2: Profile of Major Sustainability indexes

\begin{tabular}{|c|c|c|c|}
\hline Index provider & Country & Sustainability indexes & Year of launch \\
\hline SAM Group & Australia & $\begin{array}{l}\text { Australian SAM } \\
\text { Sustainability Index }\end{array}$ & 2005 \\
\hline Calvert & United States & Calvert Social Index & 2000 \\
\hline Citizens Funds & United States & Citizens Index & 1994 \\
\hline \multirow{7}{*}{$\begin{array}{l}\text { Dow Jones (DJ) and } \\
\text { SAM Group }\end{array}$} & \multirow[t]{7}{*}{ United States } & DJ World & 1999 \\
\hline & & Sustainability Indexes & \\
\hline & & $\begin{array}{l}\text { DJ Sustainability STOXX } \\
\text { Indexes }\end{array}$ & 2001 \\
\hline & & $\begin{array}{l}\text { DJ STOXX Sustainability } \\
\text { Index } 40\end{array}$ & 2001 \\
\hline & & $\begin{array}{l}\text { DJ Sustainability North } \\
\text { American Indexes }\end{array}$ & 2001 \\
\hline & & DJ Euro STOXX & 2001 \\
\hline & & Sustainability Indexes & \\
\hline \multirow{3}{*}{$\begin{array}{l}\text { Ethical Capital } \\
\text { Partners }\end{array}$} & \multirow{3}{*}{ Italy } & Ethical Index Euro & 2000 \\
\hline & & $\begin{array}{l}\text { Ethical Index Europe } \\
\text { Small Cap }\end{array}$ & 2003 \\
\hline & & Ethical Index Global & 2001 \\
\hline \multirow[t]{4}{*}{ Ethibel } & \multirow[t]{4}{*}{ Belgium } & $\begin{array}{l}\text { Ethibel Sustainable Index } \\
\text { (ESI) Global }\end{array}$ & 2002 \\
\hline & & ESI Americas & 2002 \\
\hline & & ESI Europe & 2002 \\
\hline & & ESI Asia Pacific & 2002 \\
\hline \multirow{5}{*}{$\begin{array}{l}\text { Financial Times } \\
\text { Stock Exchange } \\
\text { (FTSE) }\end{array}$} & \multirow[t]{5}{*}{ UK } & FTSE4Good Global Index & 2001 \\
\hline & & FTSE4good US Index & 2001 \\
\hline & & FTSE4Good Europe Index & 2001 \\
\hline & & FTSE4Good UK Index & 2001 \\
\hline & & FTSE4Good Japan Index & 2004 \\
\hline Janzti Research & Canada & Janzti Social Index & 2000 \\
\hline $\begin{array}{l}\text { Johannesburg Stock } \\
\text { Exchange (JSE) }\end{array}$ & South Africa & $\begin{array}{l}\text { JSE Socially } \\
\text { Responsible Index }\end{array}$ & 2004 \\
\hline $\begin{array}{l}\text { Kemplen Capital } \\
\text { Management and } \\
\text { SAM Asset } \\
\text { Management }\end{array}$ & Netherlands & $\begin{array}{l}\text { Kempen SNS Smaller } \\
\text { Europe SRI Index }\end{array}$ & 2003 \\
\hline $\begin{array}{l}\text { KLD Research and } \\
\text { Analytics }\end{array}$ & United States & $\begin{array}{l}\text { Domini } 400 \text { Social Index } \\
\text { KLD Large Cap Social Index } \\
\text { KLD Broad Market } \\
\quad \text { Social Index }\end{array}$ & $\begin{array}{l}1990 \\
2001 \\
2001\end{array}$ \\
\hline $\begin{array}{l}\text { Morningstar } \\
\text { Japan }\end{array}$ & Japan & $\begin{array}{l}\text { Morningstar Socially } \\
\text { Responsible } \\
\text { Investment Index }\end{array}$ & 2003 \\
\hline Vigeo & France & ASPI Eurozone 2001 & 2001 \\
\hline
\end{tabular}

Each sustainability index only includes companies sourced from a specific investment universe, such as European or US equities. Most indexes also cap the number of constituents, so if one company is excluded it is replaced immediately with another. The Dow Jones specialist SRI indexes have between 100 and $2 \mathrm{fi} 0$ companies each. ${ }^{172}$ Companies, 
of course, must have publicly traded stocks to be eligible for inclusion in an index. This mandate excludes some socially responsible companies that are not public firms (for example, Ikea).

The following sections look in detail at the two main sustainability indexes-the Dow Jones Sustainability Group Indexes and the Financial Times Stock Exchange (FTSE)4Good Index Series. These indexes are the most significant since their connections to major international stock exchanges in New York and London have given each a profile and level of market influence unobtainable by rival SRI indexes. Both indexes now include many financial institutions, mainly banks and investment firms that take the form of public corporations. ${ }^{173}$ They also have set benchmarks for some other SRI indexes such as Australia's Sustainable Assessment Management (SAM) Sustainability Index. ${ }^{174}$

\section{B. Dow Jones Sustainability Indexes (DJSIs)}

The DJSIs were launched in 1999 to track the financial performance of the leading CSR-driven companies worldwide. ${ }^{175}$ The first index created in this family, the Dow Jones Sustainability World Index, comprises over 300 companies that represent, using Dow Jones criteria, the top 10 per cent of the leading sustainability companies drawn from the Dow Jones Global Indexes. Other indexes added to the family include the Dow Jones Sustainability North American Index, the Dow Jones Sustainability United States Index, and the Dow Jones Sustainability European Index. ${ }^{176}$

All indexes of the DJSI family are constructed according to the same CSR criteria, which include general and industry-specific criteria, covering three areas: environmental, economic, and social performance. ${ }^{177}$ The Swiss-based SAM makes the evaluations. Using a business case model of CSR, the SAM looks at how corporate sustainability performance creates both financial risks and opportunities. It thus provides a 'financial 
quantification of corporate sustainability performance. ${ }^{\text {'17 }}$

The general SAM assessment criteria include corporate governance, environmental management and performance, human rights, supply chain management, and labour practices. This information is assimilated and verified to give each company an overall 'corporate sustainability score.' This score enables identification of leading sustainability companies in each sector. Negative screens are also applied to the DJSI World to create subset indexes that exclude companies involved in the production of tobacco, alcohol, gambling, armaments, and firearms.

Information about corporate social, economic, and environmental performance is gathered from disparate sources including general industry questionnaires, corporate documents and reports, media commentary and stakeholder reports, and direct contacts with companies. ${ }^{179}$ While the criteria and methodology behind the index is publicly available, the data collected by SAM analysts for determining the composition of each DJSI is not disclosed publicly. Independent studies, though, have found that DJSI World companies perform strongly on CSR indicators. ${ }^{180}$

To maintain the integrity of each index, a 'corporate sustainability monitoring' system applies 'to verify a company's involvement and management of critical environmental, economic and social crisis situations that can have a highly damaging effect on its reputation.' 181 The monitoring system can lead to a firm's exclusion from the DJSI. Further, each DJSI is reviewed annually and quarterly to ensure that the index composition accurately reflects the top tier of leading sustainability companies within the DJSI investable universe. ${ }^{182}$

The Design and Advisory Committees are critical to the DJSI governance. The former comprises two representatives from each of the DGSI and the SAM Group. This committee is responsible for auditing the index composition at annual and quarterly reviews, completing an ongoing review of all extraordinary corporate actions for possible changes to index 
composition, verifying the integrity of market data, and, ultimately, deciding on the composition of the index. The DJSI Advisory Committee has ten independent financial sector advisors and CSR experts. Its primary mandate is 'to give advice on possible implications for sustainability-driven portfolio management and offer input regarding the methodology.'183

\section{FTSE4Good Index Series}

The FTSE4Good Index Series was launched in July 2001 with the intention of raising funds for UNICEF by donating licensing fees from the index to support UNICEF programmes for children. By 2007 the FTSE4Good had grown to a family of five indexes covering global and major regional markets. ${ }^{184}$ They function under the auspices of the FTSE, which is based in London. The FTSE4Good indexes are derived from the parent FTSE All-Share Index (United Kingdom) or the FTSE Developed Index (Global). Unlike the DJSI, the FTSE4Good indexes are not about recognizing 'best practice' companies. Rather, they set specific standards for companies to meet if they wish to be included in the index. The FTSE4Good also differs from the DJSI in that it has a policy of active engagement and dialogue with companies. It is much more proactive than other SRI index providers in pushing companies to improve their sustainability performance. ${ }^{185}$

The FTSE4Good uses a mix of positive and negative screens, and the criteria are progressively tightened over time, such as new climate change standards. ${ }^{186}$ Screens include companies that satisfy requirements in five areas: the environment, climate change, human rights, supply chain labour standards, and countering bribery. Conversely, companies connected to tobacco, nuclear weapons, nuclear energy, or uranium mining are excluded. The FTSE4Good Policy Committee intends to eventually replace these exclusion criteria with performance-based criteria.

The FTSE4Good team has devised detailed criteria to define three dimensions of sustainability. ${ }^{187}$ Environmental criteria assign companies with a low, medium, or high 
impact weighting according to their industry sector. Higher impact sectors incur more stringent index inclusion criteria. These criteria cover corporate environmental policy, management systems, and reporting practices. For example, while a company in a high impact sector must adopt a formal EMS, a company in a low impact sector need not. ${ }^{188}$ Further, high impact companies must regularly publish a report on their environmental policies and practices, unlike lower impact sector companies.

Like the DJSI, the FTSE4Good retains an SRI consultancy group, the Ethical Investment Research Service (EIRIS), to assess companies according to the FTSE4Good criteria. EIRIS relies on company questionnaires, direct contact, and company reports for its evaluations. A specialist FTSE committee retains ultimate responsibility for decisions to include or remove a company from the indexes. The FTSE4Good Policy Committee, whose membership is drawn from corporations, academia, NGOs, and the financial sector, reviews the FTSE4Good indexes semi-annually. It also oversees the development and approval of criteria revisions or new criteria to the indexes.

The FTSE4Good indexes are influential because they are used as a basis for regional and global SRI index tracker funds and for asset selection by actively managed investment portfolios. According to the FTSE, its SRI indexes help 'investors to navigate through the plethora of corporate social responsibility (CSR) codes and standards around the world.' ${ }^{189}$ A 2004 study of the FTSE4Good's impact on corporate behaviour suggests that it has had some impact on the internal operations of listed companies, especially on their reporting, policy decisions, and management systems. ${ }^{190}$

2. SRI Research and Advocacy Bodies

A significant facet of the new transnational governance of SRI is the global network of SRI think tanks, namely research, consultancy, and advocacy bodies. This plethora of financial sector and civil society institutions, which are detailed in Table 3, contribute to sharing information, raising awareness, building consensus for action, disseminating best practice examples, and encouraging policy advocacy. They assist governance through the evaluation and ranking of corporate social and environmental performance, surveys of SRI 
market trends, and the facilitation of information about the SRI sector generally through conferences, websites, and reports. The most valuable governance function formed by these institutions is the evaluation and rating of corporate social and environmental performance for investors. This work contributes to SRI norm building in several ways. The process by which companies collect and respond to questionnaires, surveys, and other information requests may help them to reflect upon their social and environmental performance, possibly with a view to making organizational and policy changes. ${ }^{191}$ Some of these SRI research institutions have lobbied and pressured governments for reforms. For instance, Canada's Social Investment Organization has campaigned for amendments to Canadian pensions fund legislation in order to require disclosure of SRI policies. ${ }^{192}$ The SRI research and advocacy community has also critically influenced important governance questions, such as what should qualify as SRI. Table 3 lists some principal SRI associations.

\section{Table 3: Principal Socially Responsible Investment Research and Advocacy Bodies}

\section{Institution}

Association for Sustainable and Responsible Investment in Asia

BankTrack

Ethical Investment Association

Ethical Investment Research Service

Fair Pensions

Interfaith Center on Corporate Responsibility

Investor Responsibility Research Center

Shareholder Association for Research and Education

Social Investment Forum

Social Investment Organization

UK Social Investment Forum

\section{Jurisdiction}

\author{
East Asia
}

Global

Australia

United Kingdom

United Kingdom

United States

United States

Canada

United States

Canada

United Kingdom

Monitoring the financiers' observance of SRI standards and exerting pressure for 
improved compliance is another function played by these bodies and other NGOs. Broad-based environmental NGOs are increasingly scrutinizing the environmental impacts of financiers. ${ }^{193}$ Some specialize in just the financial sector, such as BankTrack, ${ }^{194}$ which monitors compliance with the Equator Principles. Apart from these civil societal institutions, market players such as associations of institutional investors have also collaborated to address SRI issues. These include the Canadian Coalition of Good Governance, ${ }^{195}$ the Council of Institutional Investors, ${ }^{196}$ and the International Corporate Governance Network. ${ }^{197}$ Several investor coalitions have formed subsidiary groups targeting specific SRI concerns. To address climate change risk, for example, investors have set up the Carbon Disclosure Project, ${ }^{198}$ which gathers information necessary for investors to assess the financial risks posed by climate change; the Institutional Investor Summits on Climate Risk, ${ }^{199}$ which provides investors with a comprehensive analysis of the financial risks associated with climate change; the Institutional Investors Group on Climate Change, ${ }^{200}$ which exchanges information about the material risks to, and opportunities for, businesses associated with climate change; and the Investor Network on Climate Risk, which addresses financial risk implications. ${ }^{201}$

Another facet is the specialist consultancy organizations, which provide SRI advice and research to investors. These include Mercer Management Consulting, ${ }^{202}$ Innovest, ${ }^{203}$ Enhanced Analytics Initiative, ${ }^{204}$ and KLD Research and Analytics. ${ }^{205}$ They evaluate corporate environmental performance, research the state of the SRI market, and provide management tools to investors wishing to integrate environmental, social, and governance factors into their financial decisions.

VI. CONCLUSIONS

The preceding commentary highlights that different governance mechanisms play different roles. These include providing normative frameworks, process standards, 
management systems, and comparative evaluation. Normative frameworks furnish guidance on best practices and acceptable performance. Process guidelines enable an organization's performance to be

assessed, verified, and communicated. Management systems guide the integration of corporate codes of conduct in strategic and day-to-day corporate management. Comparative evaluation mechanisms serve to evaluate and rank businesses collectively to assist asset selection by SRI institutions.

Are the fragmented norms and institutions of the current smorgasbord of transnational governance the most effective way to achieve a more sustainable society through the financial sector? Or do they merely tinker with the problem of irresponsible financing and thereby mask the continuation of business as usual? Certainly, the answer to these questions depends partly on available alternatives. Despite international agreements to liberalize financial services, governments retain ample authority to regulate at a national and international level the environmental impacts of investment. For instance, the General Agreement on Trade and Services in regard to financial services includes a so-called 'prudential carve-out,' which allows states to enact public interest regulation to control unwelcome side effects of financial markets. ${ }^{206}$ However, governments have declined to use the prudential carve-out power to address environmental and social problems. Nor have they been willing to collaborate to enact international financial agreements that would impose substantive standards for ethical and responsible financing. This lacuna in hard law-in both the national and international spheres - has thus been left to soft law standards to fill.

With any voluntary governance mechanism, the recurrent criticism is that they amount to 'greenwash' - a smokescreen to placate critics and enable companies to continue largely as usual. ${ }^{207}$ Given the context of a neo-liberal capitalist system, some NGOs and commentators see the Equator Principles and other SRI governance mechanisms as being incapable of achieving sustainability. ${ }^{208}$ In this perspective, SRI remains a niche market functioning within a financial sector that is unwilling to address social and environmental constraints and a system of regulation that does not favour social control over capital allocation. 
Thus, perhaps SRI can only promote meaningful change if it is nested within a governance system that includes more rigorous controls such as mandatory corporate sustainability reporting, fully cost-internalizing environmental taxes and liability rules, the democratization of financial institution governance, and greater state involvement in capital allocation such as through national pension plans, which is starting to occur in Sweden and New Zealand. ${ }^{209}$ Given the complexity and intrusiveness of such measures, they would most likely be adopted through nationallevel regulation rather than through international agreements, at present.

As the emerging SRI governance mechanisms are prone to subversion by the very market forces that they are meant to govern, how can we maintain their integrity? One reason for hope is that the very fragmented and disparate nature of these mechanisms, which span numerous codes of conduct, indexes, reporting standards, and research associations, may help minimize the risk of the entire realm being colonized or co-opted. The global network of environmental and social NGOs will also play a role in keeping pressure on the financial sector.

The behavioural impact of SRI transnational governance mechanisms lacks thorough empirical verification. This article has suggested changes in policies and behaviour of financial institutions. Many banks and investors have subscribed to codes of conduct, issued policy statements, established new organizational units, and changed their environmental risk assessment procedures. However, the impact of these changing SRI norms on the companies that they finance is much harder to determine. Given the difficulty of isolating the impact of specific variables, it is only possible to draw contingent and provisional conclusions about the impact of changes in SRI governance.

It is clear that, although SRI governance has global ambitions, the financial institutions that have thus far committed themselves to SRI standards are overwhelmingly from Western Europe and, to a lesser extent, from North America and Oceania. These are regions characterized by relatively high levels of political and civil rights, mature markets, and active 
civil society organizations. Conversely, countries without these conditions remove a major impetus for adopting a code of conduct. Thus, corporate policies and strategies are more likely to address environmental issues when demanded or induced by the institutional context of a particular company. Corporate adherences to SRI codes serve what some commentators have described as part of their 'social license' to operate. ${ }^{210}$

Another key observation is that financial institutions specializing in those services or functions with the most visibility, and with the greatest involvement in the design of a code, are most likely to adopt it. To illustrate, among the top twenty international arrangers of project finance loans, 60 per cent have signed the EPs. The EPs were developed by the banking industry, and this fact has created advantages in having the principles designed by people knowledgeable about project finance and the sense of ownership that the banking industry felt about the process. The corresponding numbers for other services or functions of lower public visibility (or those that have environmental and social impacts that are less directly traceable) are global fund managers (3fi per cent) and global financial advisers (30 per cent). ${ }^{211}$ Reputational risk appears to drive an adherence to SRI norms.

If we accept that only voluntary standards and codes are likely to be tolerated by financial markets and international policy makers in the near future, what improvements to them can we realistically expect? Three areas of reform need investigation. First, should the plethora of standards be harmonized into one or two main governance frameworks? The complexity and institutional diversity of financial markets, where financiers pursue different roles, are one reason to favour the continued evolution of sector and function-specific governance mechanisms. And, as noted earlier, the diversity of standards also protects against subversion by hostile market forces. On the other hand, some consolidation of governance tools could decrease confusion as well as the implementation costs for organizations.

A second topic for reform is to bolster the enforcement side of these voluntary 
mechanisms. Market institutions such as stock exchanges could be harnessed as surrogate regulators. For instance, we could go beyond sustainability indexes to require that each company meet environmental standards as a condition of being listed on a stock. For codes of conduct such as the Equator Principles and the UN statements, we must expand the role of the public in monitoring and enforcing these norms. Financiers should be accountable not only to their shareholders and other supporters but also to the communities whose livelihoods are affected by the projects they finance. Creating mechanisms for community accountability such as the World Bank Inspection Panel or the IFC's Office of the Compliance Advisor/Ombudsman should be a priority for the SRI codes. ${ }^{212}$ A useful feature of the Organisation for Economic Co-operation and Development's Guidelines for Multinational Enterprises is the system of 'national contact points' in the participating countries to hear complaints from the public concerning company non-compliance with the guidelines. ${ }^{213}$ While this mechanism has not always brought justice, such as the recent case involving a complaint against Australia's ANZ bank financing forestry operations in Papua New Guinea, it has the potential to do more. ${ }^{214}$

Third, SRI governance tools are primarily informational policy instruments. They serve to communicate, evaluate, and rank corporate environmental performance for interested responsible investors. Not only does such information feed the ethical concerns of investors, but it may also affect the market value of businesses by disclosing liabilities and other factors that affect earnings and profitability. ${ }^{215}$ However, it would be useful to see some direct financial incentives offered to stimulate SRI. For example, governments could offer tax concessions to SRI organizations, which would be carried out in the context of approved SRI codes of conduct.

This article thus gives cautious and highly qualified endorsement to the new transnational 
SRI governance. Lamentably, it falls short of what is needed to truly reorient capital markets towards social justice and environmental protection. Yet the limitations of alternate routes to international environmental regulation must be acknowledged. It has been governments' inability or unwillingness to regulate financial institutions and corporate conduct effectively that has prompted civil society and some responsible investors to take the lead. When governments fail to agree to regulate international financial markets, the advantages of the current potpourri of instruments become even more apparent. They help to overcome the shortcomings of global politics where agreement on inter-governmental policies and regulations can take years to happen, if at all. However, we should not be resigned to accepting this situation as the best we can achieve. The environmental crisis engulfing us demands ongoing pressure for better methods of governance for sustainability. 


\section{Notes}

1 A. Walter, World Power and World Money (1993).

2 M. Schaberg, Globalization and the Erosion of the National Financial Systems (1999).

${ }^{3}$ R. Lastra, Legal Foundations of International Monetary Stability (2006). On the European Union(EU), see R. Lastra, The Governance Structure for Financial Supervision and Regulation in Europe 10(1) Col. J. Eur. L. 49 (2003).

${ }^{4}$ C.J. Mailander, Financial Innovation, Domestic Regulation and the International Marketplace: Lessons on Meeting Globalization's Challenge Drawn from the International Bond Market 31 George Washington J. Int'l L. \& Econ. 341 at $378(1997-8)$.

5 See United Nations Principles of Responsible Investment, <www.unpri.org/principles>; and Equator Principles, <www.equator-principles.com>.

${ }^{6}$ For introductions, see P. Harrison, The Third Revolution: Population, Environment and a Sustainable World (1992); and G.D. Daly, Nature's Services: Societal Dependence on Natural Ecosystems (1997).

${ }^{7}$ See R. Sparkes, A Historical Perspective on the Growth of Socially Responsible Investment, in R Sullivan and C Mackenzie, eds., Responsible Investment, 39 (2006).

${ }^{8}$ For an overview, see M. Jeucken, Sustainable Finance and Banking: The Financial Sector and the Future of the Planet (2001); and S. Labatt and R.R. White, Environmental Finance: A Guide to Environmental Risk Assessment and Financial Products (2002).

${ }^{9}$ Social Investment Forum, 2005 Report on Socially Responsible Investing Trends in the United States: A TenYear Review (January 2006); and European Social Investment Forum, Socially Responsible Investment among European Institutional Investors (2003).

10 J. Rada and A. Trisoglio, Capital Markets and Sustainable Development 27(3/4) Col. J. World Bus. 42 (1992); and W.L. Thomas, The Green Nexus: Financiers and Sustainable Development 13 Geo. Int'l Envt'1 L. Rev. 899 (2001).

11 A. Hackethal and R.H. Schmidt, Financing Patterns: Measurement Concepts and Empirical Results, University of Frankfurt Working Paper (2003); J. Corbett and T. Jenkinson, How is Investment Financed: A Study of Germany, Japan, the United Kingdom and the United States, Manchester School Supplement, at 69 (1997).

12 S.L. Gillan and L.T. Starks, Relationship Investing and Shareholder Activism by Institutional Investors, University of Texas Working Paper (1995).

${ }^{13}$ See D. Leipziger, The Corporate Responsibility Code Book (2003); and European Commission, Employment and Social Affairs Mapping Instruments for Corporate Social Responsibility (2003).

${ }^{14}$ O. Perez, The New Universe of Green Finance: From Self-Regulation to Multi-Polar Governance, in O. Dilling, M. Herberg, and G. Winter, eds., Responsible Business: SelfGovernance in Transnational Economic Transactions (2007) [forthcoming].

${ }^{15}$ Collevecchio Declaration on Financial Institutions, <www.foe.org/camps/intl/ declaration.html>; and

UN Principles of Responsible Investment, supra note 5.

${ }^{16}$ Equator Principles, supra note 5; and Global Reporting Initiative, <www. globalreporting.org>.

${ }^{17}$ R. Falkner, Private Environmental Governance and International Relations: Exploring the Links 3 Global Envt'l Pol. 72 (2003).

${ }^{18}$ Walter, supra note 1 at 202-4; H.M. Kim, Globalization of International Financial Markets: Causes and Consequences (1999).

19 J. Braithwaite and P. Drahos, Global Business Regulation, at 7-8 (2000); and further S. Strange, The Retreat of the State: The Diffusion of Power in the World Economy (1996).

${ }^{20}$ See B.J. Richardson, Sustainable Finance: Environmental Law and Financial Institutions, in B.J. Richardson and S. Wood, eds., Environmental Law for Sustainability, 309 (2006).

${ }^{21}$ B.J. Richardson, Diffusing Environmental Regulation through the Financial Services Sector: Reforms in the EU and Other Jurisdictions 10(3) Maastricht J. Eur. \& Comp. L. 1 (2003).

${ }^{22}$ By way of introduction, see M. MacNeil, N. Sargent, and P. Swan, Law, Regulation and Governance (2003).

${ }^{23}$ Organisation for Economic Co-operation and Development (OECD), Reforming Environmental Regulation in OECD Countries (1996).

${ }^{24}$ See M. Rein, The Social Structure of Institutions: Neither Public nor Private, in S.B. Kamerman and A.J. Kahn, eds., Privatization and the Welfare State (1989); and J.Q. Wilson, The Politics of Regulation, at chapter 10 (1980).

${ }^{25}$ G.I. Balch, The Stick, the Carrot and Other Strategies: A Theoretical Analysis of Governmental Intervention, in J. Brigham and D.W. Brown, eds., Policy Implementation: Penalties or Incentives? 43 (1989).

26 S. Merry, Legal Pluralism 22(5) L. and Soc. Rev. 869 at 871 (1988).

27 See B. Krumsiek, Voluntary Codes of Conduct for Multinational Corporations: Promises and Challenges 109(4) Bus. \& Soc. Rev. 583 (2004).

${ }^{28}$ E. Morth, ed., Soft Law in Governance and Regulation: An Interdisciplinary Analysis (2005).

29 J. Braithwaite and B. Fisse, Self-Regulation and the Control of Corporate Crime, in C.D. Shearing and P.C. Stenning, eds., Private Policing, 221 at 222 (1987).

${ }^{30}$ G. Teubner, Corporate Fiduciary Duties and Their Bene4ciaries, in K.J. Hopt and G. Teubner, eds., Corporate Governance and Directors' Liabilities, 149 (1985).

31 Ibid. at 160.

32 D.J. Fiorino, Rethinking Environmental Regulation: Perspectives on Law and Governance 23 Harv. Envt'1 L. Rev. 441 at 448 (1999).

${ }^{33}$ See M.S. Baram and D.G. Partan, eds., Corporate Environmental Disclosure of Environmental Risks: US and European Law (1990). 
${ }^{34}$ J. Nash and J. Ehrenfeld, Codes of Environmental Management Practice: Assessing Their Potential as a Tool for Change 22 Ann. Rev. Energy and the Env't 487 (1997) (considering 5ve codes in terms of their generation of new environmental practices and the facilitation of cultural change in participating organizations).

35 See generally S. Wood, Voluntary Environmental Codes and Sustainability, in Richardson and Wood, eds., supra note 20 at 229; A. Mol, V. Lauber, and D. Liefferink, eds., The Voluntary Approach to Environmental Policy (2000); D. Leipziger, The Corporate Responsibility Code Book (2003); P. ten Brink, ed., Voluntary Environmental Agreements: Process, Practice and Future Use, at 37 (2002); and R.B. Gibson, ed., Voluntary Initiatives: The New Politics of Corporate Greening (1999).

${ }_{36}$ J. Moon, The Firm as Citizen? Social Responsibility of Business in Australia 30(1) Aus. J. Pol. Sc. 1 (1995).

${ }^{37}$ J. Morrison et al., Managing a Better Environment: Opportunities and Obstacles for ISO 14001 in Public Policy and Commerce, at 8-10 (2000).

${ }^{38}$ See K. Lester, Protecting the Environment: A New Managerial Responsibility, in D. Owen, ed., Green Reporting: Accountancy and the Challenge of the Nineties, 39 (1992).

39 See A.P.J. Mol, Ecological Modernisation and Institutional ReNexivity: Environmental Reform in the Late Modern Age 5(2) Envt'l Pol. 302 (1996).

${ }^{40}$ M.E. Porter and V. der Linde, Green and Competitive: Ending the Stalemate 73(5) Harv. Bus. Rev. 120 (1995).

${ }^{41}$ E. Bergman and A. Jacobson, Environmental Performance Review: Self-Regulation in Environmental Law, in G. Teubner, I. Farner, and D. Murphy, eds., Environmental Law and Ecological Responsibility: The Concept and Practice of Ecological Self-Organization, 208 (1994).

42 OECD, Voluntary Approaches for Environmental Policy in OECD Countries, at 19-20 (1999); and A. Baranzini and P. Thalmann, eds., Voluntary Agreements in Climate Policy, at 4(2004).

${ }^{43}$ See P. Bansal and K. Roth, Why Companies Go Green: A Model of Ecological Responsiveness 43 Acad. of Man. J. 717 (2000); S. Sharma, A. Pablo, and H. Vredenburg, Corporate Environmental Responsiveness Strategies: The Role of Issue Interpretation and Organizational Context 35 J. App. Behavioral Sc. 87 (1999).

44 See A. Neale, Organising Environmental Self-Regulation: Liberal Governmentality and the Pursuit of Ecological Modernisation in Europe 6 Envt'l Pol. 1 (1997); and I. Maitland, The Limits of Business Self-Regulation 27(3) Cal. Man. Rev. 132 (1995).

${ }^{45}$ For example, M. Vidovic and N. Khanna, Can Voluntary Pollution Prevention Programs Ful4ll Their Promises? Further Evidence from the EPA's 33/50 Program, 53(2) J. Envt'l Econ. \& Man. 180 (2007); and US Government Accountability Of5ce, Climate Change: EPA and DOE Should Do More to Encourage Progress under Two Voluntary Programs (April 2006).

46 Agence France Press, EU to Introduce Legislation as Car Makers Fail on Emission Targets (November 2006).

47 R.B. Gibson, Questions about a Gift Horse, in Gibson, ed., supra note 35 at 6-7.

48 OECD, supra note 42 at 31-8.

49 Ibid. at $40-2$ and 99.

${ }^{50}$ C. Wright and A. Rwabizambuga, Institutional Pressures, Corporate Reputation, and Voluntary Codes of Conduct: An Examination of the Equator Principles 111(1) Bus. \& Soc. Rev. 89 (2006).

${ }^{51}$ See T. Guay, J.P. Doh, and G. Sinclair, Non-Governmental Organizations, Shareholder Activism, and Socially Responsible Investments: Ethical, Strategic, and Governance Implications 52(1) J. Bus. Ethics 99 (2004).

52 The full text of many of these codes is available in K. McKague, Compendium of Ethics Codes and Instruments of Corporate Responsibility (2005).

${ }^{53}$ E. Morgera, The UN and Corporate Environmental Responsibility: Between International Regulation and Partnership 15(1) Rev. Eur. Comm. \& Int'1 Envt'1 L. 93 (2006).

54 See UN Global Compact, <www.unglobalcompact.org>.

55 See CERES Principles, <www.ceres.org/coalitionandcompanies/principles.php >.

56 See London Principles, <www.cityoNondon.gov.uk/Corporation/living_environment/ sustainability/sustainable 5nance.htm $>$.

57 See Sullivan Principles, <www.thesullivanfoundation.org/gsp>.

58 See UN Environment Programme's (UNEP) Finance Initiative, <www.unep5.org>.

59 See <www.unep5.org/about/index.html>.

${ }^{60} \mathrm{See}$, for example, UNEP's Finance Initiative (UNEPFI), Second Annual General Meeting of the UNEP Financial Institutions Initiative (September 1998); and UNEPFI, Managing Environmental Risks in Project Finance, Fact Sheet No. 1 (1999).

61 UNEP, Advisory Committee on Banking and the Environment, Statement by Banks on Environment and Sustainable Development (1992).

62 See <www.unep5.org/signatories/statements/ii/index.html>. For analysis, see C. Joly,

UNEP Insurance Industry Initiative on the Environment: Developments in 19962 Int'1

J. Insurance L. 171 (1997).

63 See Statement by Financial Institutions on the Environment and Sustainable Development, <www.unep5.org/signatories/statements/5/index.html>.

$64 \mathrm{Ibid}$. at clauses 2.3 and 3.1.

${ }^{65}$ For the list of signatories, see <www.unep5.org/signatories/ index.html?\&no_cache=1>. Presently, 72 per cent are from Europe, 12 per cent from Asia, and 7 per cent from North America.

${ }^{66}$ UNEPFI, UNEP Financial Institutions 1998 Survey (1999). While 60 per cent of institutions have taken steps to integrate environmental risk into credit decisions, only 20 per cent have done so for investment portfolio management.

${ }^{67}$ For a sample of its activities and achievements, see UNEPFI, 2004 UNEPFI Overview (2005).

${ }^{68}$ For example, Show Me the Money: Linking Environmental, Social and Governance Issues to Company Value (2006); The Materiality of Social, Environmental and Corporate Governance Issues to Equity Pricing (2004); and Foreign Direct Investments: Financing Sustainability: Meeting Report (2002). 
${ }^{69}$ For example, Climate Change Working Group and the Asset Management Working Group.

70 Interview with James Gifford, advisor to UNEPFI, Sydney (December 2005).

71 Ibid.

72 Ibid.

73 See UN Principles of Responsible Investment (UNPRI), <www.unpri.org/principles>.

74 The signatories are drawn mainly from North America and Western Europe, see <www. unpri.org/signatories>.

75 UNPRI, Frequently Asked Questions, <www.unpri.org/faqs>.

76 Ibid.

${ }^{77}$ Interview with the staff of the UK Social Investment Forum, London (27 February 2007).

${ }^{78}$ UN Economic and Social Council (ECOSOC), Sub-Commission on Promotion and Protection of Human Rights, Norms on the Responsibilities of Transnational Corporations and Other Business Enterprises with Regard to Human Rights, UN ESCOR, UN Doc. E/CN.4/Sub.2/2003/12/Rev.2 (2003) [UN Norms]. For a historical perspective of the UN Norms, see D. Weissbrodt and M. Kruger, Norms on the Responsibilities of Transnational Corporations and Other Business Enterprises with Regard to Human Rights 97 Am. J. Int'1 L. 901 (2003).

79 See <www.unhchr.ch>.

${ }^{80}$ UN Norms, supra note 78 at s. 14.

81 Ibid. at s. 14(a), Commentary.

82 Ibid. at Part $\mathrm{H}$.

83 The UN Norms direct states to 'establish and reinforce the necessary legal and administrative framework' to facilitate their implementation (ibid. at s. 17).

$84 \mathrm{Ibid}$. at s. 15.

85 Ibid. at s. 15(a), Commentary.

86 Ibid. at s. 15.

87 Ibid. at s. 15(c), Commentary.

88 Ibid. at s. 18.

${ }^{89}$ On the debates over the UN Norms, see D. Kinley and R. Chambers, The United Nations Human Rights Norms for Corporations: The Private Implications of Public International Law 6(3) Human Rights L. Rev. 16 (2006).

90 ECOSOC, Sub-Commission on the Promotion and Protection of Human Rights, Report of the United Nations High Commissioner on Human Rights on the Responsibilities of Transnational Corporations and Other Business Enterprises with Regards to Human Rights, UN Doc. E/CN.4/2005/91 (2005).

${ }^{91}$ United Nations, Interim Report of the Secretary-General's Special Representative on the Issue of Human Rights and Transnational Corporations and Other Business Enterprises, Doc. E/CN 4/2006/97 (22 February 2006) at 15.

92 For example, Ethical Funds Company, Proxy Voting Guidelines, <www.ethicalfunds. com/pdf2/sri/proxy_voting_guidelines.pdf $>$.

93 Interfaith Center for Corporate Responsibility, Submission by ICCR's Human Rights Working Group to the UN High Commission on Human Rights (24 September 2004), <www. iccr.org/news/ press_releases/2004/pr_hrwgsubmiss100704.htm>.

94 See Collevecchio Declaration on Financial Institutions, supra note 15.

95 Most signatories are non-governmental organizations (NGOs), see <www.foe.org/ camps/intl/ endorsements.html>.

${ }^{96}$ Equator Principles, supra note 5. T. O'Riordan, Converting the Equator Principles to Equator Stewardship 47(4) Env't 1 (2005).

97 Fresh5elds Bruckhaus Deringer, Banking on Responsibility, at 7 (July 2005).

${ }^{98}$ M. Spek, Financing Pulp Mills: An Appraisal of Risk Assessment and Safeguard Procedures, at 53 (2006).

99 See Equator Principles, supra note 5.

100 Ibid. at Principle 1.

101 Ibid. at Principle 4.

102 Ibid. at Principle 5.

$103 \mathrm{Ibid}$. at Principle 7.

104 Ibid. at Principle 6.

105 Ibid. at Principle 8.

106 Listed on the website of Equator Principles, ibid.

107 Fresh5elds Bruckhaus Deringer, supra note 97 at 1.

$108 \mathrm{Ibid}$. at 50. The Fresh5elds study also identi5ed reasons why some banks reject the Equator Principles: scepticism, necessary internal systems that are not in place, similar procedures that are already in place, and fear of 'contagion' (that is, pressure could arise to apply the principles to other arms of the bank's business) (at 65).

${ }^{109}$ See generally D.H. Schepers, The Impact of NGO Network ConNict on the Corporate Social Responsibility Strategies of Multinational Corporations 45(3) Bus. \& Soc. 282 (2006).

110 Ethical Funds Company, <www.ethicalfunds.com/do_the_right_thing/sri/shareholder_ action/shareholder_resolutions_2005/03_bank_montreal.htm $>$.

111 See Rainforest Action Network, <www.ran.org>.

112 B. Baue, Revised Equator Principles Fall Short of International Best Practice for Project Finance, in SocialFunds.com Newsroom (12 July 2006); and A. Missbach, The Equator Principles: Drawing the Line for Socially Responsible Banks? An Interim Review from an NGO Perspective 47 Development 78 (2004).

113 Equator Principles, supra note 5 at Principle 9.

114 Ibid. at Principle 10.

115 M. Chan-Fishel, Unproven Principles: The Equator Principles at Year Two, 5 (2005).

116 Ibid. at 6.

${ }^{117}$ M. Chan-Fishel, Time to Go Green: Environmental Responsibility in the Chinese Banking Sector (2007).

118 Fresh5elds Bruckhaus Deringer, supra note 97 at 10. 
${ }^{119}$ See R. Kraakman et al., When Are Shareholder Suits in Shareholder Interests? 82 Geo. L.J. 1733 (1994).

120 J. Monahan, Principles in Question, The Banker 3 (March 2005); and R. Bulleid, Putting Principles into Practice, Envt'l Finance (June 2004).

121 Barclays, Corporate Responsibility Report 2005, 20 (2006).

122 HSBC, Corporate Social Responsibility Report 2005, 12 (2006).

${ }^{123}$ BankTrack, Principles, Pro5t or Just PR? (2004); see also BTC Project Is the First Major Test of the Equator Principles, <www.equator-principles.com/btc.shtml>.

124 At <www.caspiandevelopmentandexport.com/ASP/Home.asp>.

${ }^{125}$ Pulp Mills on the River Uruguay (Argentina v. Uruguay), Request for the Indication of Provisional Measures, International Court of Justice, 13 July 2006, [1997] I.C.J. Rep. 92, in 45 I.L.M. 1025 (2006). The International Court of Justice issued a preliminary ruling against Argentina's request to halt construction of the paper mills, 5nding no grounds to order provisional relief. It has yet to adjudicate the substantive case against Uruguay.

126 International Finance Corporation (IFC), IFC and MIGA Board Approves Orion Pulp Mill in Uruguay: 2,500 Jobs to Be Created, No Environmental Harm, Press Release (21 November 2005).

127 D. Taillant, ING Group Says It Would Not Finance Pulp Paper Mills If Argentina Did Not Agree to Investment, Center for Human Rights and Environment (29 December 2005).

128 M. Spek, Financing Pulp Mills: An Appraisal of Risk Assessment and Safeguard Procedures, at 57 (2006).

129 B.J. Richardson, Environmental Liability and Banks: Recent European Developments 17(10) J. Int'l Banking L. 289 at 290 (2000).

130 Fresh5elds Bruckhaus Deringer, supra note 97 at 11.

131 Ibid. at 12.

132 See Global Reporting Initiative (GRI), <www.globalreporting.org>.

133 See GRI Sustainability Reporting Guidelines, <www.globalreporting.org/

ReportingFramework/G30nline>.

134 GRI, Financial Services Sector Supplement: Environmental Performance, Pilot Version 1.0 (March 2005).

135 Ibid. at 4.

136 KPMG, KPMG International Survey of Corporate Responsibility Reporting 2005 (2005).

137 Ibid. at 4.

138 Ibid. at 20.

139 Standard and Poor, Sustainability and UNEP, Risk and Opportunity: Best Practice in Non-Financial Reporting, 38 at 47 (2004).

${ }^{140}$ See A. Willis, The Role of the Global Reporting Initiative's Sustainability Reporting Guidelines in the Social Screening of Investments 43(3) J. Bus. Ethics 233 (2003).

141 See the GRI Register of All Reports Filed, <www.corporateregister.com/gri>.

${ }^{142}$ See J. Voorhees, Global Environmental Solutions: Management Systems and Synchronicity 28 Stetson L.R. 1155 (1999); and D. Monsma, Sustainable Development and the Global Economy: New Systems in Environmental Management 24 Vermont L.R. 1245 (2000).

143 See R. Fairley, Environmental Policy and Audit: What's in It for Us? 7 Envt'l L. \& Mgmt 31 (1995).

144 See J. Nash and J. Ehrenfeld, Codes of Environmental Management Practice: Assessing Their Potential as a Tool for Change 22 Ann. Rev. Energy \& Env't 487 (1997); and D. Monsma, Sustainable Development and the Global Economy: New Systems in Environmental Management 24 Vermont L.R. 1245 (2000).

145 See generally R. Hillary, ed., ISO 14001: Case Studies and Practical Experience (2000).

146 Council Regulation 1836/93 Allowing Voluntary Participation by Organisations in a Community EcoManagement and Audit Scheme, [1993] O.J. L168 [Regulation 1836/93].

147 See International Organisation for Standardization (ISO), <www.iso.ch>.

148 Certi5cates are issued independently of the ISO by various national and international certi5cation or registration bodies operating around the world.

149 See generally R.A. Reiley, The New Paradigm: ISO 14000 and Its Places in Regulatory Reform 22 J. Corporation L. 535 (1997).

150 See <www.isotc.iso.org>.

${ }^{151}$ For example, S. le Clue, ISO 14001: 2004. What Do Investors Need to Know? Association for Sustainable and

Responsible Investment, Brief No. 003 (May 2005).

152 Discussed in B. Furrer and H. Hugenschmidt, Financial Services and ISO 14001

28 Greener Mgmt Int'1 32 (1999).

153 O. Bisang, Green Banking: The Value of ISO 14001 Certi4cation in the Financial Sector 4 ISO 9000 + ISO 1400 News, 7 at 10 (2000).

154 Ibid. at 11 .

155 Ibid. at 10.

156 By way of introduction, see M. Palomares-Soler and P.M. Thimme, Environmental Standards: EMAS and ISO 14001 Compared 5(8/9) Eur. Envt'1 L. Rev. 24 (1996).

157 The Eco-Management Audit Scheme (EMAS) regulation stipulates that the environmental management system must comply with detailed requirements stated in the annex to the regulation. Regulation 1836/93, supra note 146 at Article 3(c).

158 Ibid.

159 Council Regulation 761/2001 Allowing Voluntary Participation by Organisations in a Community EcoManagement and Audit Scheme, [2001] O.J. L114.

$160 \mathrm{Ibid}$. at Article 14.

${ }^{161}$ Ordinance on the Inclusion of Additional Sectors, 11 October 1996 (Austrian Federal Law Bulletin No. 550); and for the EC-Eco-Audit Extension Decree, 1998, see Association for Environmental Management in Banks, Savings Banks and Insurance Companies, Time to Act: Environmental Management in Financial Institutions, at 4 (1998). 
162 Ibid. at Annex VI, clause 6.3(b).

${ }^{163}$ W. Kahlenborn and D. Dal Maso, The Eco-Management Audit Scheme: A New Opportunity for Financial Institutions, European Commission pamphlet (2001).

${ }^{164}$ See How to Open Pollution Coverage Market: Make Policy Contingent on Obeying Environmental Code 108(14) Insurance Advocate 10 (1997).

165 See E. Rafferty, Participants in Responsible Care Offered an Insurance Discount 105(2) Chemical Engineering 48 (1998); and D. Hunter, Responsible Care Earns Discount on EILPremiums 159(29) Chemical Week 11 (1997).

166 P.L. Stenzel, Can the ISO 14000 Series Environmental Management Standards Provide a Viable Alternative to Government Regulation? 37 Am. Bus. L.J. 237 at 272 (2000).

167 C. Davies, What ISO 14001 Means for the Banking Industry 106(3) Canadian Banker 8 at 9 (1999).

168 J. Nash and J. Ehrenfeld, Environmental Management Systems and Their Roles in Environmental Policy 3-4 (1999).

169 See, for example, E. Basse, The Contract Model: The Merits of a Voluntary Approach 2 Envt'1 Liability 74 (1994).

${ }^{170}$ Stenzel, supra note 166 at 284 (discussing problems with the ISO 14001's environmental goals).

171 Ibid. at 279.

172 See <www.sustainability-indexes.com>.

173 W. Baue, Banks and Financial Service Providers Figure Prominently in FTSE4Good Attrition, DJSI Matriculation, SocialFunds.com Newsroom (8 September 2005).

174 See Australia's SAM Sustainability Index, <www.aussi.net.au>.

175 See Dow Jones Sustainability Indexes (DJSI), <www.sustainability-indexes.com>.

${ }^{176}$ DJSI, Guide to the Dow Jones Sustainability North America Index and the Dow Jones Sustainability Index (September 2005).

177 Ibid.

178 Ibid. at 15 .

179 Ibid. at 10

180 J.E. Ricart, M.A. Rodriguez, and P. Sánchez, Sustainability in the Boardroom: An Empirical Examination of Dow Jones Sustainability World Index Leaders 5(3) Corporate Governance 24 (2005).

181 DJSI, supra note 176 at 13.

$182 \mathrm{Ibid}$. at 22-3.

183 Ibid. at 31.

184 Financial Times Stock Exchange (FTSE), FTSE4Good Index Series Factsheet (2006). Currently, the benchmark indices: FTSE4Good Global, FTSE4Good UK, FTSE4Good Europe, FTSE4Good US, and FTSE4Good Japan. See <www.ftse.com/Indices/FTSE4Good_Index_Series/Constituents.jsp>.

${ }^{185}$ Interview with the staff of Ethical Investment Research Service, London (22 February 2007).

186 FTSE, FTSE4Good Climate Change Criteria (2006).

187 FTSE International, FTSE4Good Index Series Inclusion Criteria (2006).

$188 \mathrm{Ibid}$. at 3.

189 FTSE, FTSE4Good Index Series Factsheet (2006).

190 G. Cobb et al., FTSE4Good: Perceptions and Performance, in Seventh Alternative Perspectives on Finance Conference (8-10 August 2004).

${ }^{191}$ See generally Å. Skillius and U. Wennberg, Continuity, Credibility and Comparability: Key Challenges for Corporate Environmental Performance Measurement and Communication, at s. 5.2 (February 1998) (noting dif5culties in comparing rating/ranking systems because the assessment methodologies have different goals).

192 B.J. Richardson, Financing Environmental Change: A New Role for Canadian Environmental Law 49(1) McGill L.J. 145 (2004).

${ }^{193}$ Worldwide Fund for Nature and BankTrack, Shaping the Future of Sustainable Finance: Moving from Paper Promises to Performance (2006); and Australian Conservation

Foundation, False Pro5ts: How Australia's Finance Sector Undervalues the Environment (2006).

194 See BankTrack, <www.banktrack.org>.

195 See Canadian Coalition of Good Governance, <www.ccgg.ca〉.

196 See Council of Institutional Investors, <www.cii.org>.

197 See International Corporate Governance Network, <www.icgn.org>.

198 See Carbon Disclosure Project, <www.cdproject.net>

199 See Institutional Investor Summits on Climate Risk, <www.incr.com>.

200 See Institutional Investors Group on Climate Change, <www.iigcc.org>.

201 See Investor Network on Climate Risk, <www.incr.com>.

202 See Mercer Management Consulting, <www.mercermc.com>.

203 See Innovest, <www.innovestgroup.com/>.

204 See Enhanced Analytics Initiative, <www.enhanced-analytics.com>.

205 See KLD Research and Analytics, <www.kld.com>.

${ }^{206}$ L.E. Panourgias, Banking Regulation and World Trade Law: GATS, EU and 'Prudential' Institution-Building (2006).

207 Perez, supra note 14; and S. Wood, Green Revolution or Greenwash? Voluntary Environmental Standards, Public Law and Private Authority in Canada, in Law Commission of Canada, ed., New Perspectives on the PublicPrivate Divide (2002).

208 Friends of the Earth, Ethical Investment in a Neo-Liberal Economy (2005).

${ }^{209}$ Superannuation and Retirement Income Act 2001 (New Zealand); Public Pension Funds Act 2000 (Sweden); and Richardson, supra note 20 at 333-4.

${ }^{210}$ N. Gunningham, R.A. Kagan, and D. Thornton, Social License and Environmental Protection: Why Businesses Go beyond Compliance 29 L. \& Social Inquiry 307 (2004). 
211 Euromoney, Project Finance Yearbook 2004/2005, at 67-70 (2005).

212 D. Hunter, The Emergence of Citizen Enforcement in International Organizations, in

D. Zaelke, ed., Making Law Work: Environmental Compliance and Sustainable Development (2005).

${ }^{213}$ OECD, Guidelines for Multinational Enterprises: Ministerial Booklet, 32 and 35-7 (2000).

${ }^{214}$ M. Lee, NGOs Find Novel Ways to Air Complaints of Alleged Environmental and Human Rights Breaches of Voluntary OECD Guidelines: ACFa and Others v. ANZ Bank 2-3 National Envt'1 L. Rev. 31 (2006).

${ }^{215}$ R. Repetto and D. Austin, Coming Clean: Corporate Disclosure of Financially Signi5cant Environmental Risks (2000); and A. Campanale, Green Investment: Incentive for Disclosure 3(1) Rev. Eur. Comm. \& Int'1 Envt'l L. 43 (1994). 